\title{
Perceptual Learning Styles of Students and its Effect to Their Academic Performance
}

\author{
Rona A. Banas \\ Master Teacher I \\ Agusan Del Sur National High School, Philippines
}

Keywords: perceptual learning style, academic performance

\section{THE PROBLEM AND ITS SETTING}

\subsection{Introduction}

Learning is assimilated in different habits and it diverges from person to person. Many studies has been piloted in support to this and they proved to be significant in the learning procedure and because of this very goal, assessing the learning preference of each individual is of great importance.

When educators are aware of their students' unique characteristics in learning, then a flexible and effective methods can be applied for better learning. Also, the success in knowing the student's learning preference will positively affect their achievement and academic performance at school however, if there is a failure in meeting these needs, their academic performance may become unfavorable.

One of the famous learning styles is Perceptual learning style. It is concerned on the ways students learn through the use of sense organs in the learning process. Perceptual learning style caught attentions to psychologists which later resulted in the production of different theories that talks and explores about this subject. Fleming's VAK (Visual-AuditoryKinesthetic) model is one of the most common and widely-used categorizations of learning styles.

Philippine educators together with the Department of Education designed instructions and strategies in order to assess these diverse learning needs for the improvement of our education system. The instructions provided inside the classrooms adapts to the students' different facets of learning. In Agusan del Sur National High School, we have observed that students possess different learning style preference and there is a need to know the effects of these preferences to their academic performance.

Although learning styles will inevitably differ among students in the classroom, teachers should try to make changes in their classroom that will be beneficial to every learning style Dunn and Dunn (1979). (Visual, Auditory, Kinaesthetic Learning Styles and Their Impacts on English Language Teaching, 2012) Knowing the learning styles of the students can help the teachers and other educators in the development of teaching that will also result to the betterment of the students' academic performance at school. This study aims to identify the Perceptual Learning Styles of Grade 12 GAS Students in Agusan Sur National High School based on Fleming's VAK Learning Style Model.

\subsection{Theoretical Framework}

Many theories and models have been developed by previous researchers exploring the "learning style" and factors concerning and related to it. Fleming's VAK (Visual-Auditory-Kinesthetic) model is one of the most common and widely-used categorizations of learning styles. The VAK model provides a simple way to explain and understand learning styles. Fleming identified three categories of learner's preference. Visual learners prefer learning through seeing such as through the use of visual aids like power point presentations and video clips. Auditory learners learns more through hearing. Discussions and the use of music will greatly help them. Kinesthetic learners depends on movement, touching, and doing. Hands-on activities and explorations arouses their interests. According to Nzesei (2015), Fleming stated that as a teacher, the use of variety of techniques gives students the best chance to succeed. 
International Journal of Trend in Scientific Research and Development (IJTSRD) ISSN: 2456-6470

\section{Conceptual Framework}

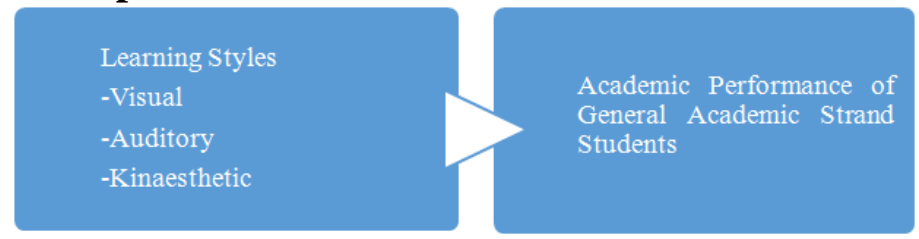

Figure1. Conceptual Framework of the Study

This study is focused on the three categories identified by Fleming (independent) and the effects of these preferences to the academic performance of the Grade 12 General Academic Strand Students in Agusan del Sur National High School (dependent).

\subsection{Statement of the Problem}

The main objective of this study is to know the Perceptual Learning Styles of Grade 12 GAS Students and its effect to their Academic Performance.

Specifically, it aimed to answer the following questions:

1. What are the Learning Styles of the students?

2. What are the Academic Performances of the students in terms of learning style?

3. Is there a significant difference between Academic Performance of the students in terms of their learning style?

Null Hypotheses:

There is no significant difference in the Academic Performance of the students in terms of their learning styles.

\subsection{Significance of the Study}

The findings of this study will be used as a foundation for constructing enhanced teaching strategies and activities to even improve the learning of students. Moreover, this study will be beneficial to the following:

Future researchers: The findings of this study will give them supplementary ideas that will help them for their future studies.

Students: This may serve as their voice in showing what learning style they are in.

Teachers: They will be able to know their student's Perceptual Learning Styles that will later help them develop strategies to improve classroom instruction and become effective teachers. They will be able to match their teaching strategies to the needs of the students.

\subsection{Scope and Delimitation}

This study is conducted at Agusan Sur National High School. There are 147 respondents in the General Academic Strand that are identified through systematic sampling. It is also focused on determining the students Perceptual Learning Style and its Effect to their Academic Performance. Other factors not stated in this section are beyond the scope of this study.

\subsection{Definition of Terms}

Academic performance: Refers to the grades of the students. In this study, academic performance will be obtained from the First Semester grades of the Grade 12 General Academic Strand students.

Perceptual learning style: The way students learn through the use of their sense organs. In this study, Perceptual Learning Style comprises the Visual, Auditory, and Kinesthetic based from Fleming's theory. Visual learners prefers learning through seeing. Auditory learners learn best through listening. Kinesthetic learners learn through involving in physical activities.

\section{REVIEW OF RELATED LITERATURE}

Learning can be defined in many ways. Learning is commonly defined as a process that brings together cognitive, emotional and environmental influences and experiences for acquiring, enhancing, or making changes in one's knowledge, skills, values, and world views (Illeris, 2004; Ormrod, 1995) as cited from Obralić and Akbarov(2012). According to (Gilakjani \& Ahmadi, 2011), learning style is sometimes defined as the characteristic cognitive, affective, social, and physiological behaviors that serve as relatively stable indicators of how learners perceive, interact with, and respond to the learning environment (MacKeracher, 2004, p. 71). Learning styles is also defined as a consistent way of functioning that reflects the underlying causes of learning behavior (Keefe, 1987). Nzesie (2015) stated that several theories and models have been developed over time by scholars in the field of learning styles.

Learning style has been a subject to many research studies and due to this, numerous theories and models were made. Below are some of the identified and known learning style theories and models.

Rita Dunn and Kenneth Dunn identified Learning Style as "The way in which each learner begins to 
concentrate, process and retain new and difficult information. That interaction occurs differently for everyone." Several studies have identified categories in determining how we learn.

Dunn and Dunn (1979) presents that "learners are affected by their: (1) immediate environment (sound, light, temperature, and design); (2) own emotionality (motivation, persistence, responsibility, and need for structure or flexibility); (3) sociological needs (self, pair, peers, team, adult, or varied); and (4) physical needs (perceptual strengths, intake, time, and mobility)". They claim that not only can students identify their preferred learning styles, but that students also score higher on tests, have better attitudes, and are more efficient if they are taught in ways to which they can more easily relate. Therefore, it is to the educator's advantage to teach and test students in their preferred styles (Dunn \& Dunn, 1978).

Kolb's model proposes that all learning entails a cycle of four learning modes, but each individual is likely to feel most comfortable in one of the four modes of the cycle based on his/her preference along two dimensions: Perception (Abstract/Concrete) nand Processing (Active/Reflective) (Kolb, 1984, 1985; Harb et al., 1985).

Divergers are those people who experience or take in information concretely, and then process what they take in reflectively (Morgan, 1995). They are sensors/feelers and watchers. Assimilators are people who take in experiences abstractly, and then they process what they take in reflectively. They are thinkers and watchers. Convergers are those persons who take in experiences abstractly and then process what they take in actively.

Another Learning Style that has emerged is Honey and Mumford's Learning Style Theory. Kolb's work formed the basis of Honey and Mumford's theory in the field of learning style and management and the development of their learning styles questionnaire (Nzesei, 2015). This theory identified four learning styles namely: activist, reflector, theorist, and pragmatism. In other words, there is arguably a strong similarity between the Honey and Mumford styles/stages and the corresponding Kolb learning styles: Activist = Accommodating; Reflector = Diverging; Theorist $=$ Assimilating; and Pragmatist $=$ Converging.
Activists (style 1), and 'Having an Experience' (stage 1 ), as the word suggest, these people likes to involve themselves into activities and experience something new every time. They enjoy immediate experiences but gets tired and bored with long-term ones. According to Hartley (1998), activists are sociable people constantly involving themselves with others but, in doing so, they seek to center all activities around themselves.

Reflector (style2), and 'Reviewing the Experience' (stage 2). Reflectors are observant and thoughtful. They think of something particularly an experience thoroughly and meticulously before making a conclusion. They are also willing to consider and see the possible angles and different perspectives before making an action. When they act it is part of a wide picture which includes the past as well as the present and others' observations as well as their own (Hartley, 1998).

Theorists (style 3) and 'Concluding from the Experience' (stage 3). Theorists adapt and integrate observations into complex but logically sound theories. They think problems through in a vertical, step-by-step logical way (Nzesei, 2015). These people are rational and wise. They tend to reject subjective judgments but tries to see a reasonable reason behind instead. They like to analyze and synthesize. They are eager on basic assumptions, principles, theories/models and systems thinking (Gregorc, 1979).

Pragmatist (style 4) and 'Planning the next steps' (stage 4). Pragmatists are fond of trying out new ideas. They apply this ideas into practice. As cited from Nzesei (2015), they are essentially practical, down to earth people who like making practical decisions and solving problems. They take problems and opportunities encountered as a 'challenge'.

One of the most common and widely used categorizations of the various types of learning styles is the Fleming's VAK model. It is a model of sensory modalities used to take in information (Fleming \& Mills, 1992).

Visual learners prefers learning through the use of eyes or seeing. They think in pictures; visual aids that represent ideas using methods other than words, such as graphs, charts, diagrams, symbols, etc. (Fleming \& Mills,1992). Nilson (2003) noted that these learners 
International Journal of Trend in Scientific Research and Development (IJTSRD) ISSN: 2456-6470

organize knowledge in terms of spatial are significant on academic achievement interrelationships among ideas and store it (Vaishnav\&Chirayu, 2013).

graphically.

Auditory Learners learn best through the sense of hearing. Lectures, discussions and playing of audio tapes help them. Fleming and Mills (1992) also noted that people with this type of preference want to sort things out by speaking first, rather than sorting out their ideas and then speaking. They will learn best when they can hear themselves express their ideas (Nilson, 2003).

Kinesthetic learners or tactile learners as identified by Fleming and Mills (1992) prefer to learn via experience-moving, touching, and doing. They are also said to value greatly their own experiences. They learn best by being active, and they often rely on physical interaction in order to master a concept (Sarasin, 1998).

Though a lot of theories and models are made, all of them supports and centers at the idea that individuals learn in several unique ways. This can be used as basis in making classroom instructions for the better learning of the students. According to (Graf, Liu, \& Kinshuk, 2010), previous studies have reported that students' learning performance could be improved if proper learning style dimensions could be taken into consideration when developing any learning or instructional process.

A study conducted by Vaishnav and Chirayu (2013) on the analysis of learning styles prevalent among secondary school students also tried to find out the relationship and effect of different learning styles on academic achievements of students as cited from Nzesei (2015). Howard Gardner's VAK learning style brain box and VAK Learning Style Inventory by Victoria Chislett and Alan Chapman was used to identify the preferred learning style of the 200 randomly selected students from the class 9th, 10th and 11th standard of Maharashtra state. Findings of the study showed that, kinesthetic learning style was more frequent than visual and auditory learning styles among secondary school students. There exist positive high correlation between kinesthetic learning style and academic achievement $(\mathrm{r}=0.658)$. The other two learning styles have positive relationship but not strong one: $r=0.287$ for auditory learning style and $r=0.129$ for visual learning style. The main effects of the three variables - visual, auditory and kinesthetic

Impact of learning styles on the academic achievement of secondary school students was also conducted in Iran (JilardiDamavandi, Mahyuddin, Elias, Daud, \&Shabani, 2011). The Kolb Learning Style Inventory (1999) was administered in eight public schools in Tehran where a sample of 285 Grade 10 students were randomly selected. The mean of test scores in five subjects, namely English, science, mathematics, history and geography, was calculated for each student and used as a measure of academic achievement.

The results of the analyses revealed that there is significant difference in the academic achievement of the Iranian students that correspond to the four learning styles; in particular, the mean scores for the converging and assimilating groups are significantly higher than for the diverging and accommodating groups (Nzesei, 2015).

A quantitative descriptive-correlational study of Bangcolan.d, determine correlation between learning styles and academics. The participants consisted of 304 nursing students who were randomly selected from eight nursing schools in Marawi City. According to (Bangcola, n.d), the four perceptual learning styles (Visual, Auditory, Tactile, Kinesthetic) have been used by the students simultaneously as major learning style. Most of the respondents are Kinesthetic which showed $78 \%$ of the total sample population while Group learning style gotthe minor and negligible preference. She also stated that Teachers should be aware that efficacy with more learning styles will allow students to achieve the optimal learning environment (Bangcola, n, d. )

Previous descriptive research of C. Castolo and L. Rebusquillo (2006) analyzed the learning styles of the PUP Laboratory High School. The findings shows that although they use varied learning styles, the most dominant is the Auditory learning style. The result also implies that their academic performances significantly differ when grouped according to gender, socio-economic status, and learning styles. Castolo and Rebusquillo (2006) recommended that the PUP-laboratory High School should maintain academic and non-academic programs which addresses the strengths and weaknesses of the students. 
From these studies, we can infer that becoming aware of the different learning styles of the students, the teachers will be able to assess these needs and match with their teaching and through this, the academic performance and competence of the students will become higher and eventually, students will excel in school.

By understanding different learning styles, teachers may gain insights into ways of making academic information more accessible to diverse groups of learners and an increased awareness of individual learning styles can help educators impart new information in a memorable way (Brady, 2013). "Of course, we may not know every detail; however, being aware of our students' learning styles, psychological qualities and motivational differences will help us regulate our lessons appropriately and according to the conditions (McCarthy, 1982; Felder, Silverman, 1988; Coffield et al., 2004).

In this present study, Neil Fleming's VAK learning style model is adapted to identify the Perceptual Learning Style of the Grade 12 General Academic Strand students and its effects to their academic performance.

\section{RESEARCH METHODOLOGY}

\subsection{Research Design}

This non-experimental study was descriptivecomparative since the researchers wants to know the Perceptual Learning Styles of the Grade 12 General Academic Strand Students and compare their Academic Performance when grouped according to their Learning Styles. This is done by giving them survey questionnaires.

\subsection{Participants of the Study}

The students that were included in the study comes from the five Grade 12 General Academic Strand sections that has a total population of 232. The total calculated sample size of respondents in this study using Slovin's formula is 147 with 5 percent margin of error. Names of all the students are taken and systematic sampling technique is used to get 147 random respondents.

\subsection{Settings of the Study}

The study was conducted in Agusan del Sur National High School (ASNHS). It has a total senior high school student population of 685 S.Y. 2017-2018, of whom GAS curriculum are 232.

\subsection{Research Instruments}

The instrument used in gathering data is in the form of self-assessment questionnaires by Victoria Chislett MSc \& Alan Chapman of 2005. The questionnaire is composed of 30 statements. 10 items corresponds to each of the Learning Styles. These are given to know the Perceptual Learning Styles of Grade 12 GAS Students in Agusan Sur National High School based on Fleming's VAK Learning Style Model.

\subsection{Data Gathering Procedure}

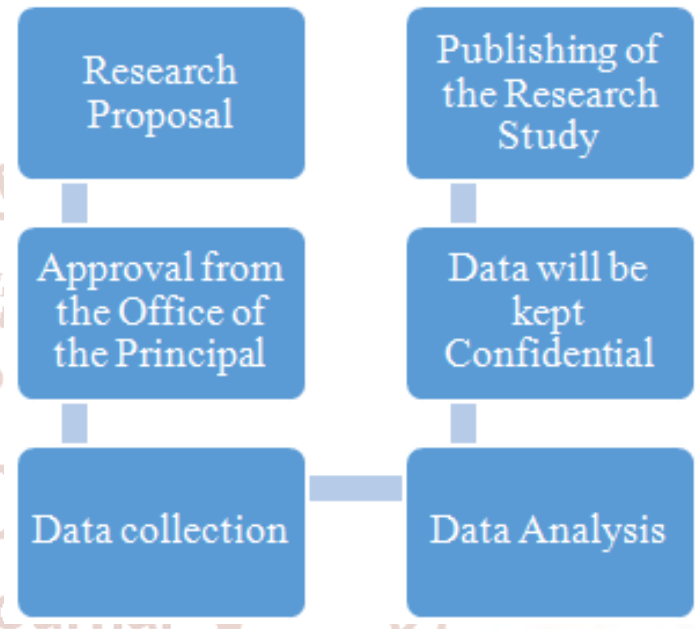

The data for this research is collected using a selfassessment questionnaire. The questionnaire comprises 10 statements per Learning Style with a total of 30 statements overall. Participants are given time to answer the questionnaire and the survey was collected right after the participants had finished answering. No incentives was given for participating in the research. The data then was computed, analyzed and interpreted by the researchers. It serves as the basis in finding out the Perceptual Learning Styles of the Grade 12 GAS Students in Agusan Sur National High School.

\subsection{Data Analysis}

The statistical tool used to interpret the gathered data are:

Frequency: This is used to determine the most frequent learning style preferred by the respondents.

Mean: Used in describing the Academic Performance of the students based on their Perceptual Learning Style.

Percentage: This is used to identify the strength of the student's learning style preference from the population. 
International Journal of Trend in Scientific Research and Development (IJTSRD) ISSN: 2456-6470

ANOVA: This is used to compare the means of the Academic Performance of the students when grouped according to their Perceptual Learning Style.

Table 3.6.1 Perceptual Learning Style Preference of the students

\begin{tabular}{|c|c|l|}
\hline Scale & $\begin{array}{c}\text { Qualitative } \\
\text { Description }\end{array}$ & \multicolumn{1}{|c|}{$\begin{array}{c}\text { Qualifying } \\
\text { Statement }\end{array}$} \\
\hline $111-147$ & Most & Preferred by most. \\
\hline $74-110$ & Majority & Preferred by many. \\
\hline $37-73$ & Some & Preferred by several. \\
\hline $1-36$ & Few & Least preferred. \\
\hline
\end{tabular}

Table 3.6.2 Academic performance of the students in Terms of Learning Style

\begin{tabular}{|l|c|l|}
\hline Description & Scale & \multicolumn{1}{|c|}{$\begin{array}{c}\text { Qualifying } \\
\text { Statement }\end{array}$} \\
\hline Outstanding & $\begin{array}{c}90- \\
100\end{array}$ & $\begin{array}{l}\text { The student excels in } \\
\text { class. }\end{array}$ \\
\hline $\begin{array}{l}\text { Very } \\
\text { Satisfactory }\end{array}$ & $85-89$ & $\begin{array}{l}\text { The student performs } \\
\text { desirably in class. }\end{array}$ \\
\hline Satisfactory & $80-84$ & $\begin{array}{l}\text { The student performs } \\
\text { well in class. }\end{array}$ \\
\hline $\begin{array}{l}\text { Fairly } \\
\text { Satisfactory }\end{array}$ & $75-79$ & $\begin{array}{l}\text { The student passed but } \\
\text { needs further assessment }\end{array}$ \\
\hline $\begin{array}{l}\text { Did Not Meet } \\
\text { Expectation }\end{array}$ & $\begin{array}{c}\text { Below } \\
75\end{array}$ & $\begin{array}{l}\text { The student needs great } \\
\text { guidance and attention. }\end{array}$ \\
\hline
\end{tabular}

\section{PRESENTATION, ANALYSIS INTERPRETATION OF DATA}

Data were analysed to identify, describe and explore the different learning style preference of Grade 12 GAS students of Agusan Sur National High School and determine its effect to their academic performance. The questionnaire includes the respondent's profile such as name and their average grade during the first semester. A total of 147 selfassessment questionnaires by Victoria Chislett MSc \& Alan Chapman of 2005 were distributed to the selected respondents. It is composed of 30 statements where 10 of which corresponds to each of the learning style identified by Neil Fleming in his VAK Learning Style Model. The gathered data are computed and presented in tables shown below.

\section{RESULTS}

Table 4.1 Perceptual Learning Style Preference of the students

\begin{tabular}{|l|c|c|c|}
\hline $\begin{array}{c}\text { Perceptual } \\
\text { Learning } \\
\begin{array}{c}\text { Styles } \\
\text { Description }\end{array}\end{array}$ & Frequency & Percent & Qualitative \\
\hline Visual & 70 & $48 \%$ & Some \\
\hline Auditory & 44 & $30 \%$ & Some \\
\hline Kinesthetic & 25 & $17 \%$ & Few \\
\hline $\begin{array}{l}\text { Visual/ } \\
\text { Auditory }\end{array}$ & 8 & $5 \%$ & Few \\
\hline Total & 147 & $100 \%$ & \\
\hline
\end{tabular}

As shown in Table 1, four types of learning style preferences emerged from this study: visual learning style topped the list with $48 \%$; followed by auditory (30\%); kinesthetic (17\%); one type of bimodal preference also emerged: visual and auditory with $5 \%$. This means that Visual and Auditory is the commonly used perceptual learning style of the students. Also, only few are inclined in Kinesthetic (25 students) and the combination of Visual and Auditory with 8 students.

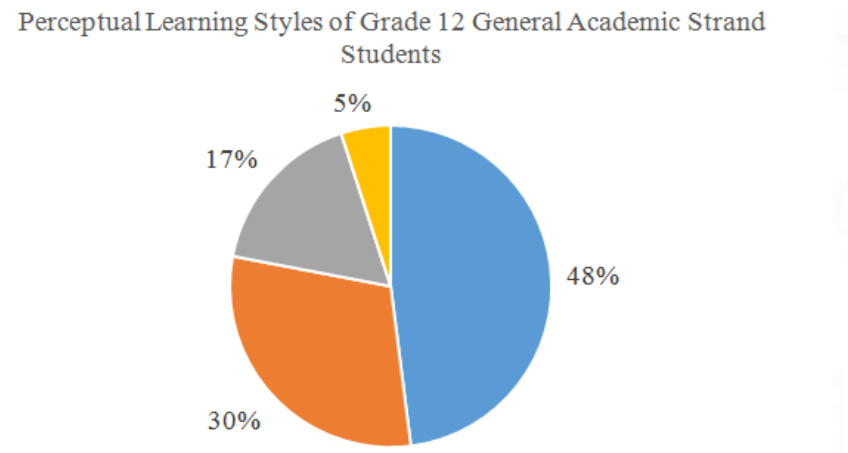

"VISUAL " AUDITORY " KINESTHETIC "VISUAL/AUDITORY

Figure2. Overall Perceptual Learning Style Preference of Grade 12 GAS Students

The figure indicates that most of the students prefer Visual Learning (48\%); followed by Auditory Learning with $30 \%$ and; Kinesthetic Learning (17\%). It also shows one bimodal learning style: Visual/Auditory with the lowest percent of 5\% from the whole sample population.

It suggests that most of the students acquire information through seeing. They prefer learning through thinking in pictures. It is followed by the Auditory learners who learns through discussions and prefers talking other than creating visual images. Few of the students likes to participate in class through 
hands-on activities. There are also students who possess a combination of perceptual learning style modalities (Visual/Auditory). They process information through seeing, hearing and speaking.

Table 4.2 Perceptual Learning Style Preference of the students

\begin{tabular}{|l|c|l|}
\hline $\begin{array}{c}\text { Perceptual } \\
\text { Learning } \\
\text { Styles }\end{array}$ & $\begin{array}{c}\text { Means of the } \\
\text { 1st Semester } \\
\text { Grades }\end{array}$ & $\begin{array}{c}\text { Qualitative } \\
\text { Description }\end{array}$ \\
\hline Visual & 90 & Outstanding \\
\hline Auditory & 90 & Outstanding \\
\hline Kinesthetic & 88 & Very Satisfactory \\
\hline $\begin{array}{l}\text { Visual/ } \\
\text { Auditory }\end{array}$ & 87 & Very Satisfactory \\
\hline
\end{tabular}

The table indicates that Visual and Auditory learners have the highest mean of 90 in the first semester grades; followed by kinesthetic learners $(\mu=88)$ and lastly, the bimodal learners (Visual/Auditory) with the mean of 87. It also reveals that Visual and Auditory learners perform outstandingly in class and both Kinesthetic and Visual/Auditory learners respond desirably to class.

The results suggest that Visual and Auditory learners excels in class mainly because their Perceptual Learning Styles are assessed well by the strategies of the teachers. It can also be said that Kinesthetic and Visual/Auditory learners performs desirably in class but providing them with activities that suits their learning styles can make them achieve even higher in class.

Table 4.3 ANOVA

\begin{tabular}{|c|c|c|c|c|c|}
\hline & $\begin{array}{c}\text { Sum of } \\
\text { Squares }\end{array}$ & df & $\begin{array}{c}\text { Mean } \\
\text { Square }\end{array}$ & F & Sig. \\
\hline $\begin{array}{c}\text { Between } \\
\text { Groups }\end{array}$ & 139.863 & 2 & 69.932 & 6.438 & .002 \\
\hline $\begin{array}{c}\text { Within } \\
\text { Groups }\end{array}$ & 1564.273 & 144 & 10.863 & & \\
\hline Total & 1704.136 & 146 & & & \\
\hline
\end{tabular}

The study indicates that the academic performance of the students in terms of their perceptual learning style is significant at 0.002 level. Therefore we can say that the students' perceptual learning style do make an impact on their overall academic performance.

The main effects of the three variables - visual, auditory and kinesthetic are significant on academic achievement (Vaishnav\&Chirayu, 2013).

\section{SUMMARY, CONCLUSIONS RECOMMENDATIONS}

AND

\section{Summary}

This study is conducted mainly to know the Perceptual Learning Styles of the G-12 GAS Students and Its Effects to their Academic Performance in Agusan del Sur National High School. Review of related literature is done and survey is conducted which led to the information indicated below.

\section{The Problem}

1. What are the Perceptual Learning Styles of the G12 GAS students?

2. What are the Academic Performances of the students in terms of learning style?

3. Is there a significant difference between Academic Performance of the students in terms of their learning style?

\section{The Procedure}

The data for this research was collected using a questionnaire. The survey is in the form of a structured questionnaire. It is comprised of the 3 different styles of Perceptual Learning that Fleming's proposed in his VAK Learning Style Model where 10 statements are provided in each respective category. The researchers also included some personal details like name and average grade in first semester. After the teacher validated the questionnaire, these were distributed to the identified Grade 12 GAS students. Participants were given time to answer the questionnaire and the survey was collected right after the participants had finished answering. The confidentiality of the respondents are assured. Also, no incentives were given for participating in the research.

The data then was computed, analyzed and interpreted by the researchers. It serves as the basis in finding out the Perceptual Learning Preference of the grade 12 GAS students in Agusan Sur National High School.

\section{The Findings}

The following findings are obtained based on the analysis and interpretation of data.

1. The Perceptual Learning Style of the Grade 12 General Academic Strand are arranged in descending order as follows:

$>$ Visual Learning $(48 \%)$

$>$ Auditory Learning $(30 \%)$

$>$ Kinesthetic Learning (17\%)

$>$ Visual/Auditory $(5 \%)$ 
2. The Academic Performance of the students in terms of their Perceptual Learning Style reveals that students who performs excellently in class are mostly Visual and Auditory learners. Both Kinesthetic and Visual/Auditory learners respond desirably to class.

3. Since the calculated value 0.002 is lesser than the probability value 0.005 , there is a significant difference. Therefore, the students' Perceptual Learning Style affects their Academic Performance.

\section{CONCLUSION}

1. Visual and Auditory are the commonly used perceptual learning style of the students. Also, only few are inclined in Kinesthetic and the combination of Visual and Auditory.

2. In terms of Perceptual Learning Style, the students who performs outstandingly are mostly Visual and Auditory Learners. Both Kinesthetic and Visual/Auditory learners respond desirably to class.

3. The Perceptual Learning Style of the students affects their Academic Performances.

\section{RECOMMENDATIONS}

As synthesized from the findings and conclusions, the following recommendations were made:

1. The Visual aids that represent ideas using methods other than words, such as graphs, charts, diagrams, symbols, etc. will be very useful for Visual learners.

2. Lectures, discussions and playing of audio tapes best suits the Auditory learners (Fleming \& Mills, 1992).

3. Kinesthetic students learn best by being active, and they often rely on physical interaction in order to master a concept (Sarasin, 1998) therefore, role playing and other physical activities will be beneficial for them.

4. On the other hand, the identified bimodal learners (Visual/Auditory) can benefit from the combination of the teaching strategies that fits to both mentioned learning style.

Being able to understand each of the learners will help in developing the learning of the students as it well assess their different facets of learning. Although learning styles will inevitably differ among students in the classroom, teachers should try to make changes in their classroom that will be beneficial to every learning style Dunn and Dunn (1979).
A good match between students' learning preferences and instructor's teaching style has been demonstrated to have positive effect on student's performance (Harb \& El-Shaarawi, 2006).

\section{REFERENCES}

1. Bangcola, A. A. (n.d.). International Journal of Learning, Teaching and Educational Research, 15(4) 22-31. Retrieved from https://www.ijlter.org/index.php/ijlter/article/view File/666/285

2. Brady, C. (n.d.). Understanding learning styles: Providing the optimal learning experience. International Journal of Childbirth Education, 28(2), 16-19.

3. Castolo, C. L., \& Rebusquillo, L. R. (2007-2008). i-managers Journal on Educational Psychology, vol. 1 no. 3 .

4. Coffield, F., Moseley, D., Hall, E., \& Ecclestone, K. (2004). Learning styles and pedagogy in post16 learning: A systematic and critical review.

5. Dunn, R., \& Griggs, S. (2003). Synthesis of the Dunn and Dunn Learning Style Model: Who, What, When, Where, and So What?

6. Dunn, R., \& K., D. (1978). Teaching students through their individual learning styles: A practical approach.

7. Dunn, R., \& K., D. (1979). Learning -styles/teaching styles: Should they... Can they... Be Matched? Retrieved from http://www.ascd.org/ASCD/pdf/journals/ed_lead/e 1_197901_dunn.pdf

8. Felder, R. M., \& Silverman, L. K. (1998). Learning and teaching styles in engineering education. Retrieved from Engineering education.

9. Fleming, N., \& Mills, C. (1992). VAK/VARK Modalities. $\quad$ Retrieved from http://www.parentcenterhub.org/wpcontent/uploads/2016/11/VARK-TBDG.pdf

10. Gilakjani, A., \& Ahmadi, S. (2011). International Conference on Social Science and Humanity. Retrieved from http://www.ipedr.com/vol5/no2/104-H10249.pdf

11. Graf, S. L., \& Kinshuk. (2010). Analysis of learners navigational behavior and their learning styles in an online course. Journal of Computer Assisted Learning, 26(2). 
International Journal of Trend in Scientific Research and Development (IJTSRD) ISSN: 2456-6470

12. Gregorc, A. F. (1979). Learning Styles: Differences with the profession must address. .

13. Harb, J., Terry, R., Hurt, P., \& William, K. (1995). Teaching through the cycle: Applications of learning style theory to engineering education at Brigham Young University. .

14. Hartley, J. (1998). Learning and Studying: A research perspective. .

15. JilardiDamavandi, A., Mahyuddin, R., Elias, H., Daud, S., \&\& Shabani, J. (2011). Academic Achievement of Students with Different Learning Styles. International Journal of Psychological Studies.
16. Keefe, J. W. (1987). Retrieved from http://erepository.uonbi.ac.ke/bitstream/handle/11 295/93142/Mutua_A\%20correlation\%20study\%2 Obetween $\% 20$ learning\%20styles \%20and\%20acad emic \%20achievement $\% 20$ among $\% 20$ secondary $\%$ 20school.pdf? sequence $=1 \&$ isAllowed $=\mathrm{y}$

17. Kolb, D. A. (1984). Experiential Learning. .

18. Kolb, D. A. (1985). Learning Style Inventory and Technical Manual.

19. Kolb, D. A. (1999). Learning style inventory. Version

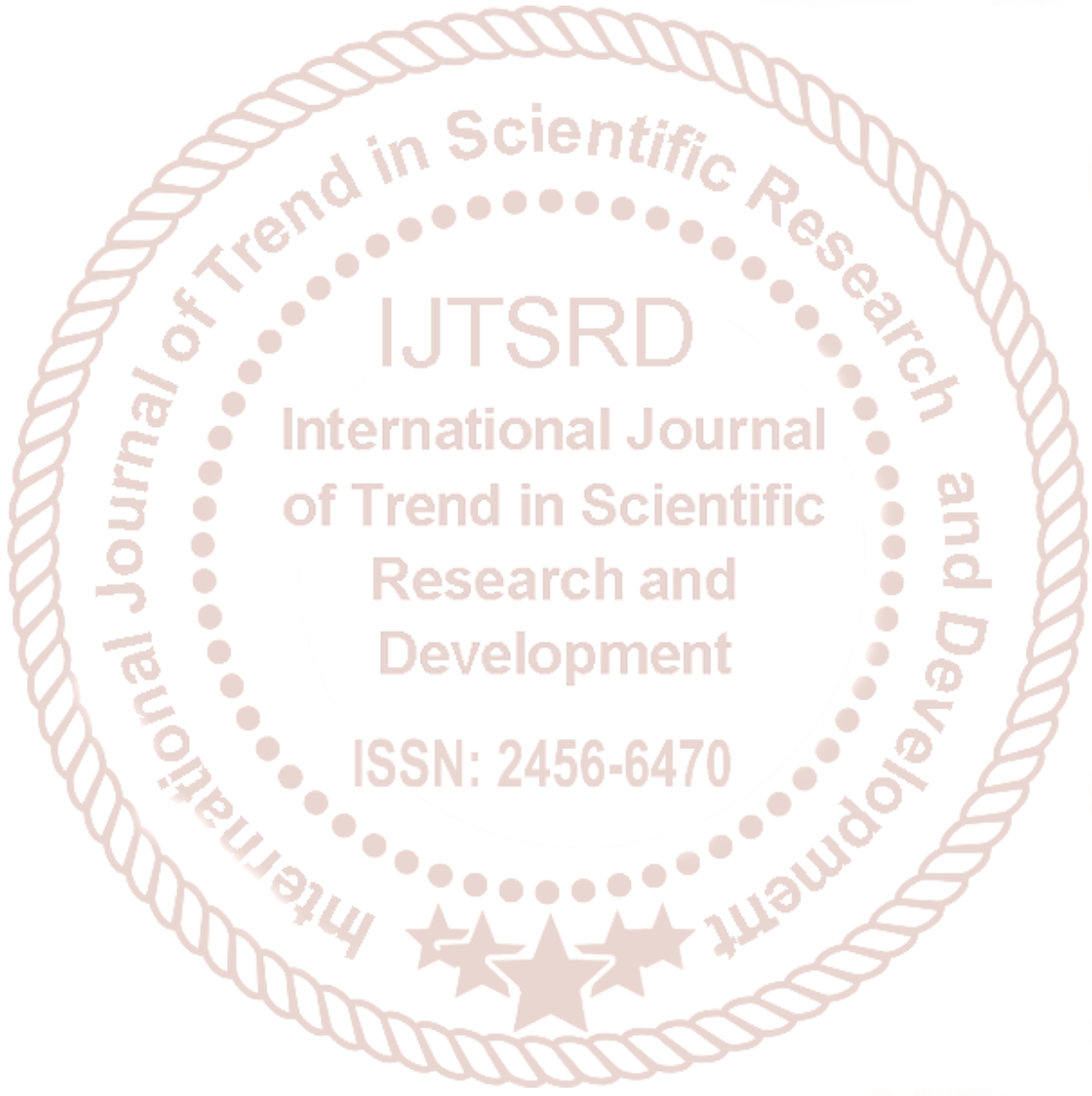

